\title{
CARPATHIAN-BLACK SEA CONTINENTAL MARGIN OF TETHYS. OCEANIC ANOXIC EVENTS
}

\author{
Y.M. Senkovsky, Y.V. Koltun, M.V. Shapovalov
}

\section{КАРПАТО-ЧОРНОМОРСЬКА КОНТИНЕНТАЛЬНА ОКРАЇНА ТЕТІСУ. ОКЕАНІЧНІ БЕЗКИСНЕВІ ПОДІї Ю.М. Сеньковський, Ю.В. Колтун, М.В. Шаповалов}

\begin{abstract}
Paleooceanographic analysys of Carpathian-Podolian-Black Sea segment of Tethys and geochemical investigations of rocks allowed to reconstruct the depositional environments and characterize the different age black shale rocks within the Ukrainian part of Carpathian flysch belt, adjacent part of East-European platform and Black Sea region, which reflect the main oceanic anoxic events in sedimentological record and form potential petroleum-source rock sequences.

Key words: Tethys, continental margin, sedimentogenesis, anoxic events, organic matter.
\end{abstract}

Палеоокеанографічний аналіз Карпато-Подоло-Чорноморського сегменту океану Тетіс і геохімічні дослідження порід дозволили відтворити умови седиментації та виділити і охарактеризувати відклади різновікових чорносланцевих порід, розповсюджених в межах української частини Карпатського флішового поясу, прилеглої частини Східно-Європейської платформи та Причорноморського регіону, що відображають в седиментологічному літописі основні океанічні безкисневі події» і формують потенційно нафтогазоматеринські товщі.

Ключові слова: Тетіс, континентальна окраїна, седиментогенез, безкисневі події, органічна речовина.

Завдячуючи широко розгорнутим океанологічним дослідженням та глибоководному бурінню, здійснюваному з судна «Гломар Челленджер», починаючи з сімдесятих років минулого століття, настав новий, якісно відмінний стан розвитку літологічної науки. Багатий фактичний матеріал став основою для з'ясування природи давнього седиментогенезу та літогенезу, визначення закономірностей формування і поширення осадів на континентальних окраїнах і за їх межами в Світовому океані.

В стратисфері Землі, як відомо, найбільшими запасами вуглеводнів характеризуються відклади крейдового періоду. Проведені океанологічні дослідження, зокрема результати глибоководного буріння (DSDP та інші) дали геологам підстави висунути концепцію про те, що саме з крейдовими відкладами морського походження пов'язане максимальне нагромадження органічної речовини і запасів вуглеводнів (8) (рис. 1) в глобальному масштабі $(2,11,12$ та ін). Ця концепція, на нашу думку, може сприяти вирішенню окремих питань генезису вуглеводнів та формування їх покладів, склала основу вивчення авторами статті «безкисневих подій» в седиментаційному літописі на прикладі КарпатоЧорноморського сегменту континентальної окраїни океану Тетіс.

Важливим фактором, який сприяє ефективному захороненню органічної речовини в осадах, як відомо $(2,4,11), є$ дефіцит кисню в мулових і придонних водах, що є вирішальним чинником в утворенні потенційно нафтоматеринських порід. Тому ідентифікація давніх «океанічних безкисневих подій» у стратиграфічному літописі осадових відкладів дозволяє деталізувати уявлення про генезис та просторово-часове поширення нафтогазоносних товщ.

Термін «океанічні безкисневі події» (OAE - oceanic anoxic events) був введений в літературу Шлягером і Дженкінсом (12) на основі аналізу глобального розповсюдження крейдових відкладів, збагачених розсіяною органічною речовиною. Такі відклади були виявлені програмою DSDP в осадових розрізах континентальних окраїн Тихого, Атлантичного, Індійського океанів, а також в цілому ряді інших сучасних та давніх морських басейнів, зокрема в Альпійсько-Середземноморському регіоні, що дало можливість розглядати їх генезис, як всесвітнє океанографічне явище. Вікові інтервали, з якими пов'язане глобальне поширення товщ, збагачених розсіяною органічною речовиною, а саме баремальбський та сеноман-туронський, були виділені дослідникамим, як окремі крейдові океанічні безкисневі події. Їх існування викликане сукупністю глобальних факторів таких, як одна з найбільших в історії Світового океану трансгресій, спричинена збільшенням швидкості спредінгу океанічного дна, збільшенням об'єму серединноокеанічних хребтів, відсутністю льодових шапок на полюсах. Результатом стало встановлення неконтрастного клімату, значне зменшення швидкості глибоководної циркуляції, стійка стратифікація і збіднення киснем океанічних вод і встановлення режиму стагнації. За 

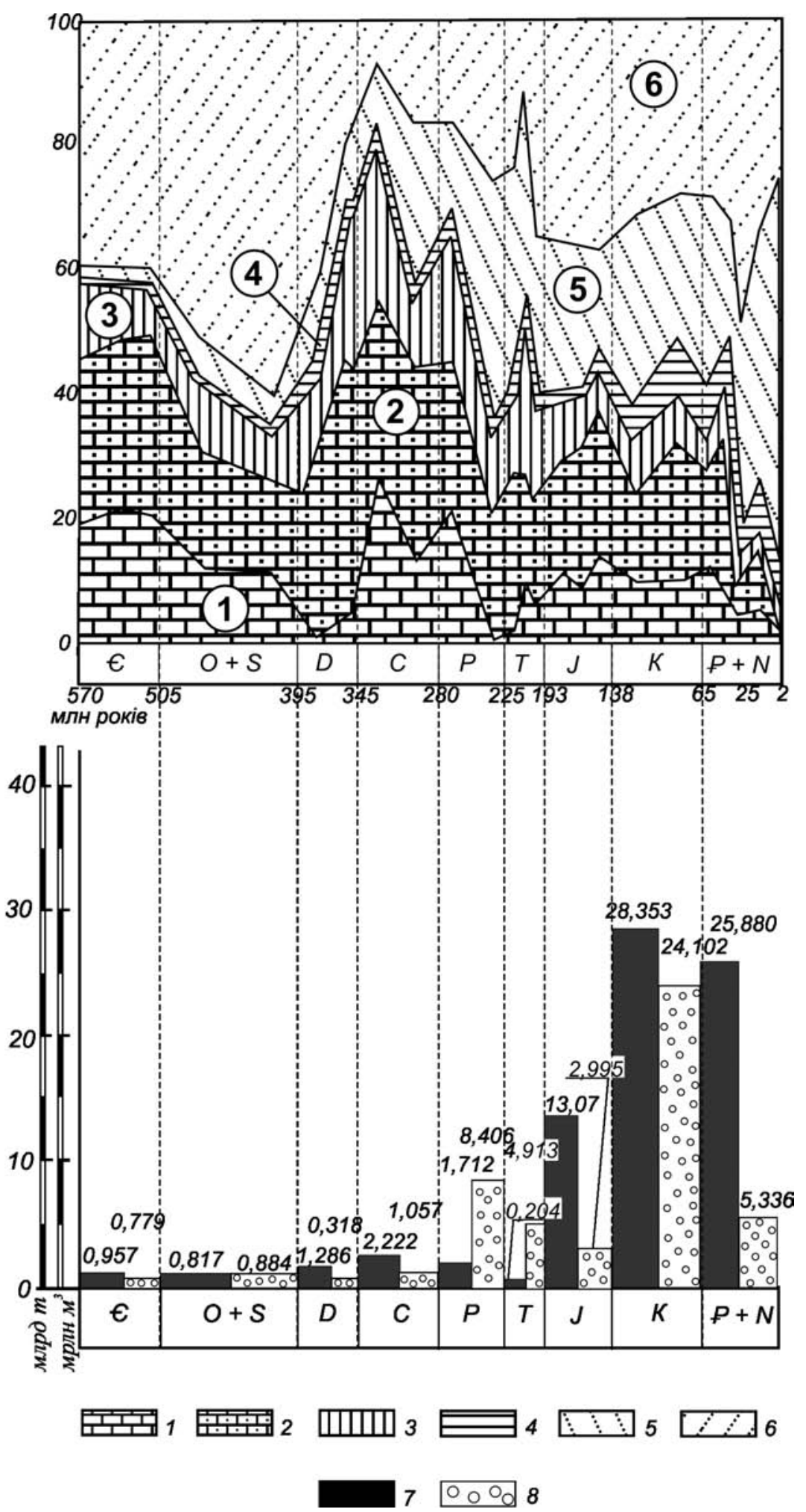

Рис. 1. Схема кількісного розподілу запасів вуглеводневої сировини у відкладах фанерозою та їх співставлення з глобальним розвитком осадових формацій. (зіставлення діаграм Ю. Сеньковським (8))

Осадові формації: 1 - карбонатні; 2 - карбонатно-теригенні; 3 - підводно вулканогенні; 4 - наземно-вулканогенні; 5 - наземні уламкові; 6 - морські уламкові. Ронов А. Б., Хаін В. Є., Булаховский А. Н., Сеславінский К. Б., 1976.

Запаси вуглеводнів: 7 - нафта; 8 - газ. Ліндтроп Н. Н., 1970. оцінкою (2) стійкий шар кисневого мінімуму існував в товщі океанічних вод на протязі згаданих вище епох від глибин менше 300 м до 2000-3000 м. На перетині шару кисневого мінімуму з континентальною окраїною на границі осадок-вода, завдяки анаеробному середовищу в придонних водах і в осадах, існували сприятливі умови для ефективної фосилізації органічної речовини.

Карпато-Чорноморський седиментаційний басейн протягом пізнього мезозою-раннього кайнозою являв собою сегмент північно-західної континентальної окраїни океану Тетіс. В той час, як в науково-пізнавальному відношенні вивченню цього району присвячені численні фундаментальні праці 3 тектоніки, стратиграфії, літології тощо, розробці проблеми самостійної дисципліни багатогалузевого характеру, якою sensu proprio $€$ палеоокеанографія давніх седиментаційних басейнів (геологічна, хімічна, біологічна), на жаль у вітчизняній геологічній науці не надано належної уваги. Тільки в останні два десятиліття цей науковий напрям став успішно реалізуватися розробкою окремих ґрунтовних досліджень. Чільних результатів в контексті геологічної та геохімічної палеоокеанографії давніх континентальних окраїн одержано авторами статті на прикладі вивчення тетидної частини Карпато-Чорноморського регіону та його суміжних областей. Викладені в цій праці матеріали становлять синтез результатів комплексних досліджень з проблем геологічної, фізичної, хімічної та біологічної палеоокеанографії крейдовопалеогенового періоду КарпатоПодоло-Чорноморського сегменту океану Тетіс. 


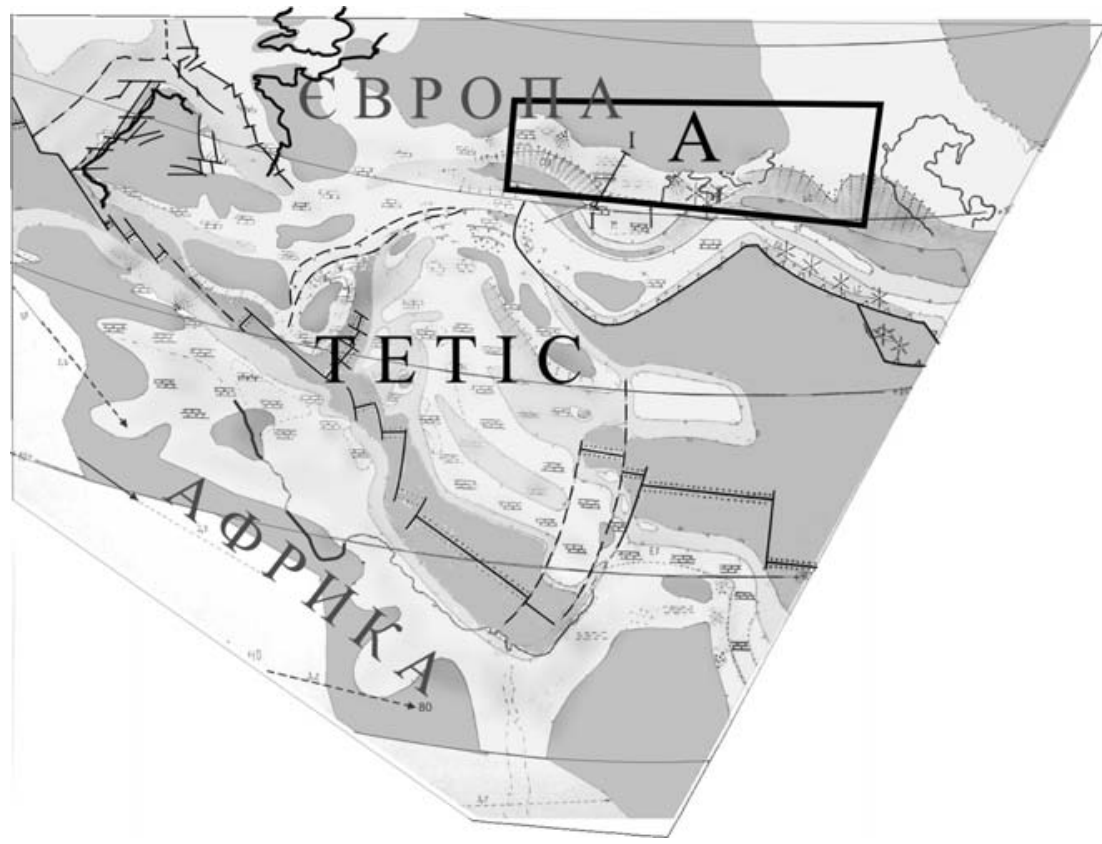

Рис. 2. А - фрагмент седиментологічно-палеоокеанографічної карти Карпато-Кавказького сегменту Тетісу. Модифіковано Ю. М. Сеньковським за Dercoure et al., 1984
В пізньому мезозої-ранньому кайнозої сучасна територія Українських Карпат та прилеглі до неї регіони Передкарпатського, Закарпатського прогинів і Подоло-Чорноморський регіон складали обширну пелагічну область Карпато-Чорноморського сегменту океану Тетіс (10). Тут, на думку (3), простежувалися окремі приконтинентальні моряседиментаційні басейни (Західно-Карпатський, Східно-Карпатський, Магурський, Сілезький, Панонський, Чорноморсько-Кавказький та ін.). Простягався він у суб-широтному напрямку і розміщувався в межах 28-35० північної широти (рис. 2.). На сході цей океанічний пелагіальний басейн сполучався з Великокавказьким, Мізійським та Захід-

но-Понтідським. На південному заході він переходив у Валахський та Австро-Альпійський басейни, а в напрямку на північний захід через море-протоку (Північно-Німецький, Малопольський та Львівський басейни) зв'язувався з широкими Центрально-Європейським та Північним морями.

Карпато-Чорноморський басейн був тісно пов'язаний з динамічною системою Світового океану. Завдячуючи сформованій системі циркуляції водних мас у Середземноморській провінції, відкритому зв 'язку з глибинними зонами Світового океану, географічному положенню та певній структурі Карпатської континентальної окраїни, тут, в зонах приберегового апвелінгу, активно проходив підток холодних вод, збагачених біогенами ( $\left.\mathrm{SiO}_{2}, \mathrm{P}, \mathrm{N}\right)$, у верхні верстви відкритого морського басейну, зумовлюючи спалах первинної біогенної продукції $\left(\mathrm{C}_{\text {орг }}\right)$ (Карпатський прибережний крейдовий та олігоценовий апве-

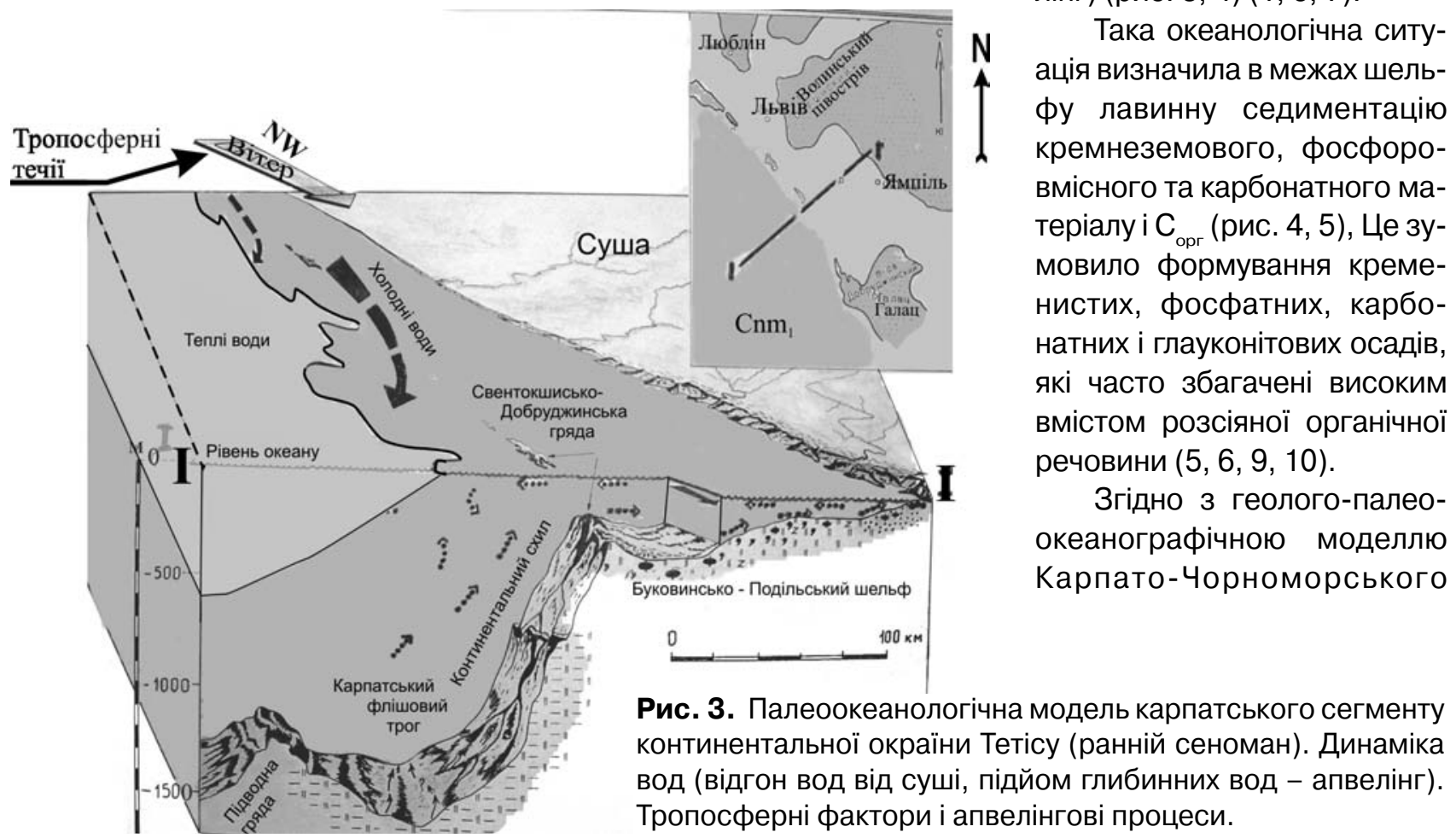
лінг) (рис. 3, 4) (1, 6, 7).

Така океанологічна ситуація визначила в межах шельфу лавинну седиментацію кремнеземового, фосфоровмісного та карбонатного матеріалу і С ${ }_{\text {орг }}$ (рис. 4, 5), Це зумовило формування кременистих, фосфатних, карбонатнх і глауконітових осадів, які часто збагачені високим вмістом розсіяної органічної ечовини $(5,6,9,10)$.

Згідно з геолого-палеоокеанографічною моделлю Карпато-Чорноморського 


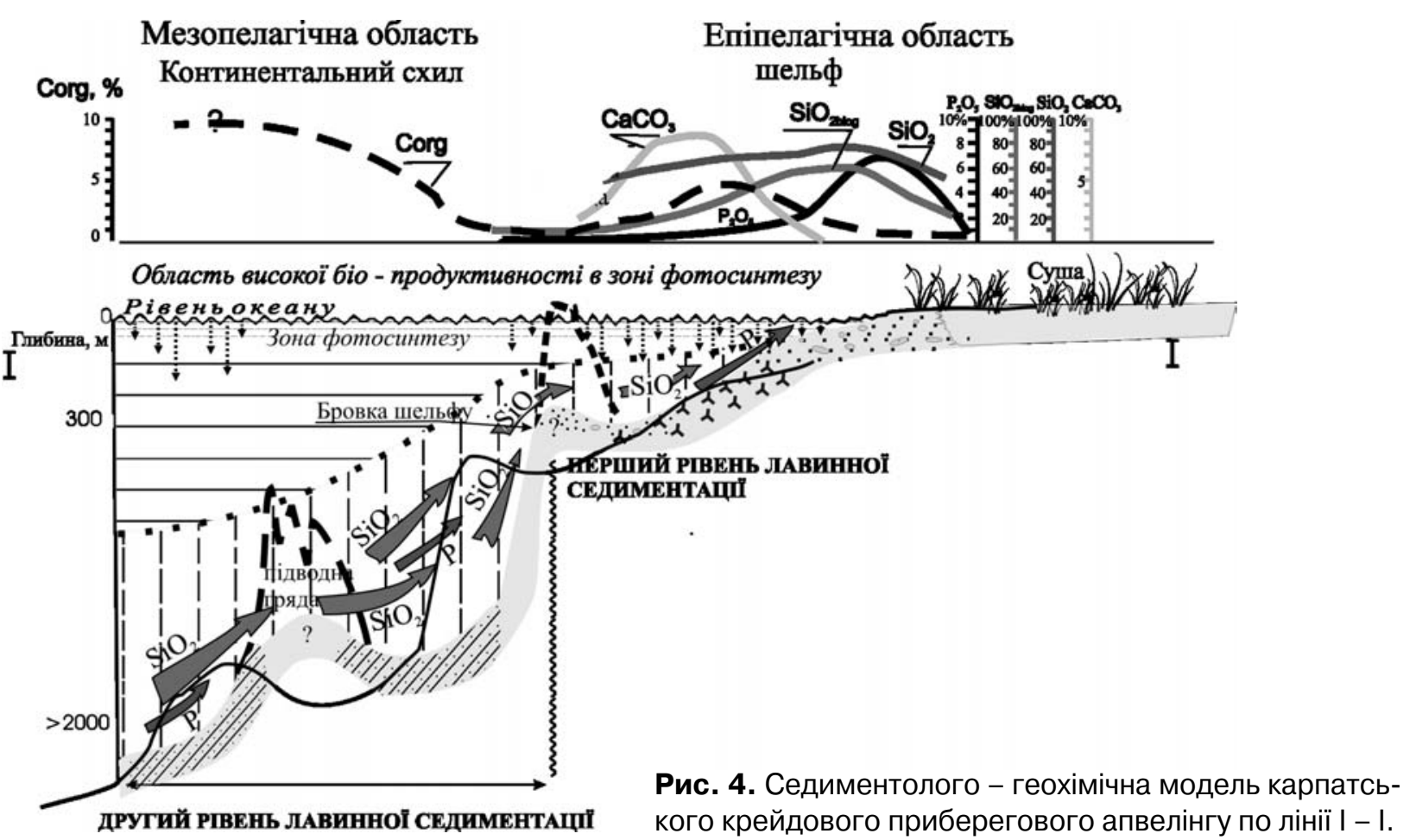

сегменту Мезо-Тетісу в структурі цього регіону $(6,10)$ простежувалися три головні морфологічні елементи - шельф, континентальний схил та його підніжжя. Рисунок 3 ілюструє структурно-морфологічну модель (карту-схему) поширення епіпелагіальної та мезопелагіальної областей у межах цього сегменту.

У будові давнього Карпато-Чорноморського шельфу вбачаємо два його океанографічні елементи: внутрішню та зовнішню зони. Внутрішня зона сучасних шельфів, охоплених апвелінгом, як відомо, характеризується найбільшим коефіцієнтом вертикального розподілу світла у водному стовпі, де його величина коливається від 1:1 до 1:10, охоплюючи глибини до 50-60 м. Цей ефект забезпечує в зоні фотосинтезу найвищу первинну продукцію фіто- й зоопланктону, що спричиняє поступання в донні осади колосальних мас $\mathrm{C}_{\text {орг. }}$, та високий розквіт бентосних організмів. Важливе значення в гідрологічному відношенні для цієї зони мають сезонний прибереговий апвелінг глибинних океанічних вод, а також інтенсивність і масштаби відгону теплих поверхневих водних мас тропосферними течіями. Всі ці обставини зумовлюють формування певних комплексів відкладів, притаманних виключно внутрішній зоні шельфу. Певні генетичні типи порід альб-сеномансь-

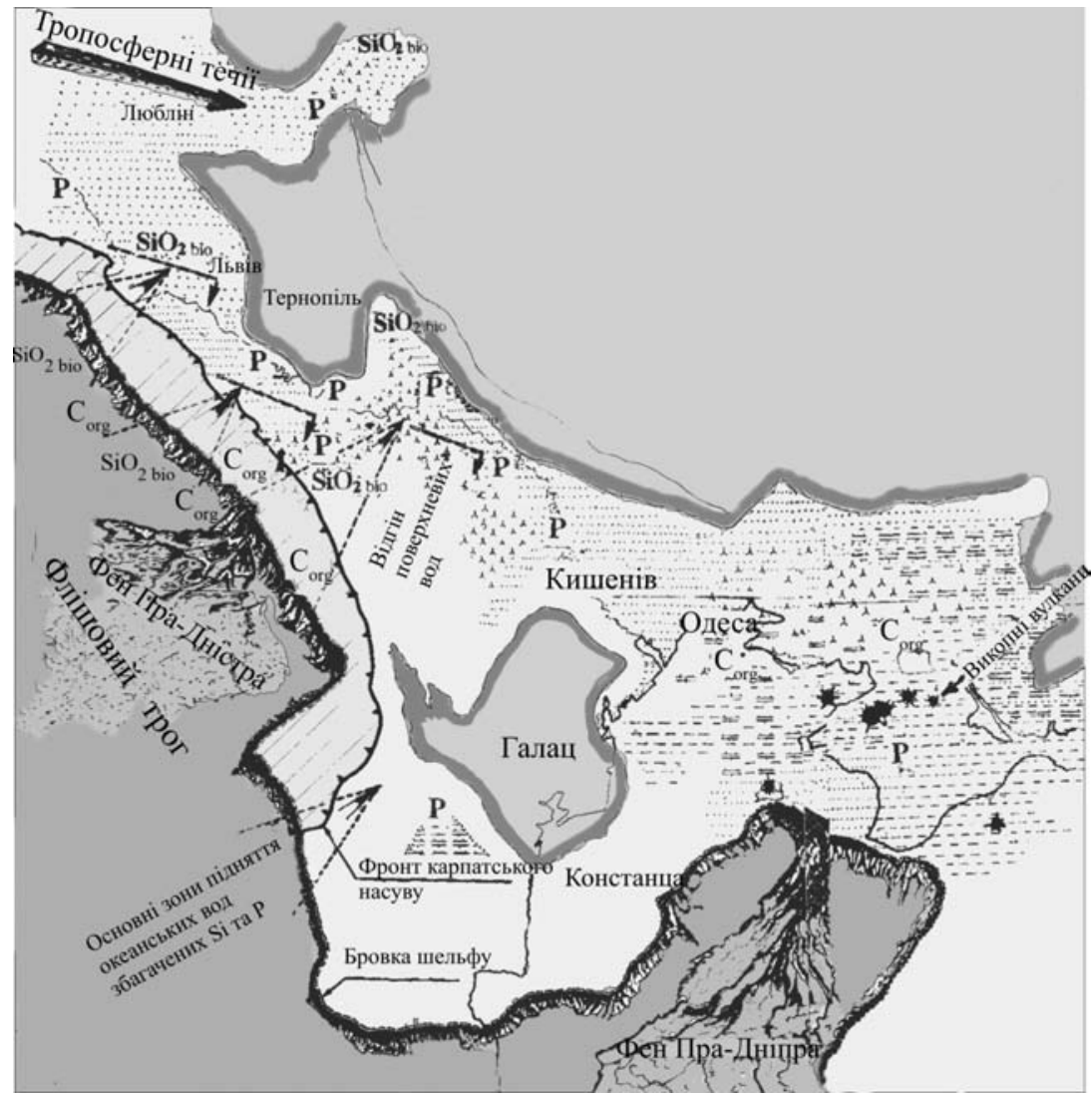

Pис 5. Область седиментації осадів, збагачених $\mathrm{SiO}_{\text {2бію. }}$ P i $\mathrm{C}_{\text {орг }}$ Зона карпатського апвелінгу (альб - сеноман). 


\section{Ю.М. СЕНЬКОВСЬКИЙ, Ю.В. КОЛТУН, М.В. ШАПОВАЛОВ}

ких відкладів з фосфорною мінералізацією та вмістом високо залізистих глауконітів фіксують простягання смуги внутрішнього шельфу в будові Буковинсько-Подільської та Покутської давньої морської відмілини.

Простягання внутрішньої та зовнішньої зон крейдового шельфу в межах Чорноморської частини регіону було встановлено К. Григорчуком та В. Гнідцем (10). На основі аналізу кількісного і видового складу біоти ці автори відтворили для сантон-кампанського часу положення та розвиток по латералі осадків, які сформувалися в описаних зонах палеошельфу. Ці дані доповнюють існуючі уявлення про природу біогенної седиментації та нагромадження карбонатних біогенних осадів пізньої крейди у відкритій частині Чорноморського басейну. В прикладному відношенні одержані результати становлять новий палеоокеанографічний критерій прогнозування розміщення на шельфі Чорного моря можливих резервуарів акумуляції вуглеводнів.

В Карпатсько-Чорноморському регіоні зовнішня зона крейдового палеошельфу характеризувалася нагромадженням тонкозернистого та глинистого матеріалу. I тільки на окремих етапах еволюції басейну домінували у їі епіпелагічній і мезопелагічній частинах певні процеси седиментогенезу. Перевагу в цих процесах мало біогенне осадконагромадження. Так, висока біопродукція кремнеорганізмів в альбі, сеномані та осідання седиментів багатих $\mathrm{C}_{\text {орг }}$, частково в сантон-кампані та олігоцені призвела до синхронного нагромадження як в епіпелагічних (платформових), так і в мезопелагічних (Карпатський фліш) регіонах нагромадження $\mathrm{SiO}_{2}$ і $\mathrm{C}_{\text {орг }}$ (кремнеаргіліти шипотської, спаської та менілітової світ Карпат, опоки, трепела, гези, спонголіти, халцедоноліти, платформи). I навпаки, пишний розвиток нанопланктону з кальцієвою функцією і його випадіння в осадок разом із кварцово-глинистим матеріалом позначився на формуванні вапнистих теригенних товщ стрийської серії (пізня крейда) флішу Українських Карпат і крейдово-мергельної формації турон-маастрихтського віку платформової частини території.

Характерною структурно-морфологічною формою континентальної окраїни Карпато-Чорноморського сегменту океану Тетіс є бровка материкової обмілини, яка фіксувала собою своєрідний плавний уступ в сторону континентального схилу. В рель'єфі шельфу вона позначалася своєрідною смугою (пасмом), морфологія якої в багатьох місцях ускладнювалася поперечними улоговинами, глибокими ущелинами, що врізалися в тіло значно давніших літифікованих порід (дивись рис. 2, 3).

Головними районами найінтенсивнішого руйнування бровки шельфу Карпато-Чорноморського басейну були місця розвитку фенів, таких як Пра-Вісла, Пра-Стрий, Пра-Покуття (?), Пра-Дніпро. Ці припущення підтверджуються наявністю відомої давньої «Коломийської» тектонічної долини на Покутті, викопного Журавненського (район с.Журавне) сантон-кампанського конуса виносу (долина Пра-Стрия, піднасув Карпат), положенням поперечного до краю платформи Устечківського палеограбена, а також потужного конуса виносу Пра-Дніпра.

При скиді теригенного матеріалу на площину схилу осади в його межах, як правило, неакумулювалися. Вони проскакували ділянку певної ширини, що була нахилена в сторону підніжжя, і починали нагромаджуватися тільки в підніжжі, формуючи фенові споруди, або включалися в турбідні потоки, утворюючи флішову товщу. Цю ділянку редукційної, або від`ємної седиментації на схилі континенту виділяємо під назвою схилова зона седиментації.

Таким чином, седиментаційний літопис Карпато-Подоло-Чорноморського сегменту океану Тетіс фіксує свідоцтва різноманітних океанологічних, тектонічних, фізико-географічних, біогеохімічних та інших подій, що впливали на еволюцію регіону і дозволяє, зокрема, прослідкувати як у просторі так і в часі розвиток безкисневих подій. Вони зумовили нагромадження потужних товщ, збагачених розсіяною органічною речовиною та, ймовірно, відіграли вирішальну роль у формуванні нафтогазових систем регіону. Протягом крейдового і палеогенового періодів, як виникає з проведених досліджень, карпатський сегмент Тетісу був охоплений трьома фазами «безкисневих подій» - ОАЕ-1 барем-альб, ОАЕ-2 - пізній сеноман-турон, і фазою в олігоцен-ранньому міоцені, яку автори вперше виділили під індексом ОАЕ-4. Остання зафіксована в розрізах менілітової та майкопської світ. Фази OAE-3 - коньяк-сантон в наших розрізах не встановлено.

«Океанічна безкиснева подія» OAE-1 позначилася в розрізах як мезопелагічних (фліш) так і епіпелагічних осадів континентальної окраїни океану Тетіс. У розрізі Карпатського флішу, що формувався в найглибшій частині басейну, відклади барем-альбського віку представлені потужною чорносланцевою товщею спаської і шипотської світ. Евксинізовані осади цього ж віку складають також епіпелагічні 
відклади піднасуву Карпат, а також розвинуті в Причорноморсько-Кримському регіоні. Таким чином, зона кисневого мінімуму в цей час охоплювала значну частину континентальної окраїни Карпато-Чорноморського сегменту Тетісу.

Сеноман-туронська «океанічна безкиснева подія» (фаза ОАЕ-2), що спричинилася до формування «чорних глин» в медитеранському басейні та Атлантичному океані, не знайшла чіткого вираження в осадах карпатського флішу, які нагромаджувались у відносно глибоководній частині мезопелагіалі. Проте, наявність численних прошарків «чорних глин», що виповнюють стилолітові шви в туронських вапняках, відкритих свердловинами в піднасуві Карпат, а також встановлена авторами наявність верств «чорних глин» в розрізі туронських пітонеллових вапняків Поділля (с.Золотники Тернопільської обл.), фіксує обширні регіональні умови евксинізації північного сегменту океану Тетіс.

Чорносланцеві відклади олігоценового-ранньоміоценового віку хоча і не мають глобального поширення, охоплюють значні території північної частини Тетісу, а їх утворення є результатом широкомасштабної регіональної «безкисневої події». В Карпатському басейні це спричинилося до нагромадження потужної чорносланцевої товщі менілітової світи, а в Причорноморсько-Кримсько-Кавказькому регіоні - відкладів майкопської світи. Дана «безкиснева подія» була пов'язана з існуванням середньоглибинного шару кисневого мінімуму, що виник у товщі вод в результаті інтенсивної поставки органічної речовини під зоною Карпато-Чорноморського приберегового апвелінгу.

В той час, як мезозойські і палеоген-неогенові безкисневі події в Світовому океані знайшли своє яскраве відображення в седиментаційному літописі багатьох осадових басейнів Світу, зокрема і в межах Карпато-Чорноморської частини континентальної окраїни океану Тетіс, інформація про більш давні безкисневі події, їх розвиток в просторі і часі та ймовірний вплив на нафтогазонагромадження $€$ ще недостатньо вивчені. Прикладом цього є вендська апвелінгова (калюська світа, миньковецький фосфоритоносний горизонт) та силурійська чорносланцеві товщі, які є наслідком давнього седиментогенезу в умовах «океанічних безкисневих подій».

Ідентифікація «океанічних безкисневих подій» в седиментаційному літописі осадових басейнів, аналіз причин їх виникнення та їх наслідків, що мають вирішальний вплив на біогеохімічні процеси на всіх стадіях літогенезу, дозволяють зрозуміти особливості поширення як у просторі, так і в часі потенційних нафто-газоматеринських відкладів, а на основі літолого-геохімічних даних моделювати подальшу еволюцію нафтових систем і оцінювати перспективи нафтогазоносності регіонів.

1. Досин Г.Д. Некоторые особенности условий седиментации олигоценовой эпохи в пределах внешне карпатской геосинклинали // Материалы Х Конгр. Карп.-Балкан. Геол.. ассоц.: Седиментология. Секция 2. - Братислава, 1974. - С. 59-63.

2. Кеннет Дж.П. Морская геология. - Москва.: Мир. 1987. - Т. 1.- 400с., Т. 2.- 384c.

3. Пастернак С.І., Сеньковський Ю.М., Гаврилишин В.І. Волино-Поділля у крейдовому періоді. - К.: Наук. Думка, 1987. - 260 с.

4. Романкевич Е.А. Геохимия органического вещества в океане. - Москва.: Наука, 1977. - 256 с.

5. Сеньковский Ю.Н. Литогенез кремнистых толщ югозапада СССР. - Киев: Наук. думка, 1977. - 280 с.

6. Сеньковский Ю.Н. Палеоокеанография Карпатского мелового апвеллинга // Геол.. журн.. - 1978. - №6. C. 54 .

7. Сеньковский Ю.Н. Карпатский меловой апвеллинг и седиментогенез // Материалы XI Конгр. Карп.-
Балкан. геол. ассоц.: Литология. - Киев: Наук. думка, 1980. - С. 170-178.

8. Сеньковский Ю.Н., Демченко Н.В. Палеогеографические реконструкции положения территории нефтегазоносных провинций Украины в фанерозое // Геология и геохимия горючих ископаемых. - 1988. Вып. 70 - С.13-22.

9. Сеньковский Ю.Н., Глушко В.В., Сеньковский А.Ю. Фосфориты запада Украины. - К.: Наук. Думка, 1989. - 144 c.

10. Сеньковський Ю., Григорчук К., Гнідець В., Колтун Ю. Геологічна палеоокеанографія океану Тетіс. - Київ: Наук. думка, 2004. - 172 с.

11. Demaison G.J., Moore G.T. Anoxic environments and oil source bed genesis. Amer. Assoc. Petrol. Geol. Bull. 1980. - Vol.64, No. 8. - P.1179-1209.

12. Schlanger S.O., Jenkyns H.C. Cretaceous oceanic anoxic events: causes and consequences. Geologie en Mijnbouw. - 1976. - Vol. 55, No 3-4. - P. 179-184. 